\title{
高分子ゲルによる摩擦挙動 \\ Friction Behavior of Polymer Gels
}

\section{和田 真人}

山形大学大学院 理工学研究科 機械システム工学専攻技術専門職員 ソフト\&ウェットマター工学研究室 ॠ 992-8510

山形県米沢市城南 4-3-16

Masato WADA

Soft and Wet matter Engineering Laboratory (SWEL), Deptment of Mechanical Systems Engineering, Graduate School of Science and Engineering, Yamagata University 4-3-16, Jonan, Yonezawa, Yamagata, 992-8510, Japan

\section{古川 英光}

山形大学大学院 理工学研究科 機械システム工学専攻教授

ソフト＆ウェットマター工学研究室 † 992-8510

山形県米沢市城南 4-3-16

Hidemitsu FURUKAWA Soft and Wet matter Engineering Laboratory (SWEL), Deptment of Mechanical Systems Engineering, Graduate School of Science and Engineering, Yamagata University 4-3-16, Jonan, Yonezawa, Yamagata, 992-8510, Japan
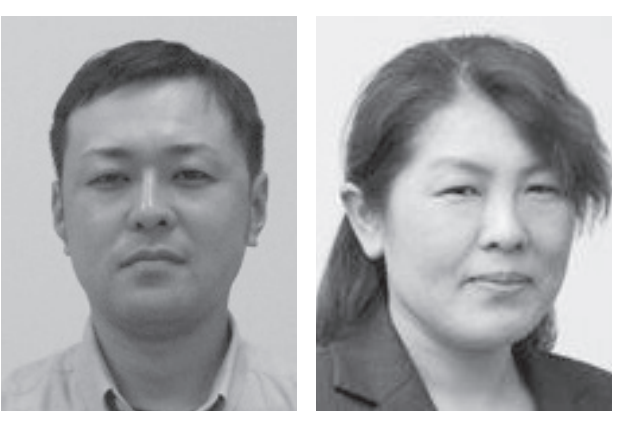

宮 瑾

山形大学大学院 理工学研究科

機械システム工学専攻助教

ソフト\&ウェットマター工学研究室

干 992-8510

山形県米沢市城南 4-3-16

Jin GONG

Soft and Wet matter Engineering

Laboratory (SWEL), Deptment of Mechanical Systems Engineering, Graduate School of Science and Engineering, Yamagata University 4-3-16, Jonan, Yonezawa, Yamagata, 992-8510, Japan

論文要旨：高分子ゲルの摩擦挙動においては，未だ測定・評価法が確立されておらず，機械材料や医療用 材料への応用の観点から早急な評価法の確立が求められている。そのためには，様々な高機能高分子ゲルの 摩擦デー夕を取得し, 個々のデータに関して議論することが必要である。そこで, 本稿では我々が取組んで いる機能性高分子ゲルの摩擦測定・評価法，および機械・医療システムへの応用展開の可能性について述べる。

Abstract: The friction measurement and evaluation of macromolecule gels has not been established yet. However for the application of the gels as industrial and medical materials, it should be established immediately. It is necessary to discuss the acquisition of frictional data of various high-performance macromolecule gels. Here we review our recent progress and mention its applicability to mechanical and medical systems.

Key words: friction, high strength gels, ball on disk measurement, shape memory, soft and wet material, hydrogel

\section{1 はじめに}

化学結合による 3 次元網目構造を持った高分子骨格と 多量の液体成分（溶媒）から構成される高分子ゲルは,

連絡者: 和田 真人

E-mail : m.w@yz.yamagata-u.ac.jp
プラスチックやゴムなど他の高分子と比べ, 低強度・低 弾性率で，しかも脆性的な材料である場合が多かった。 このことは，例えば身近な高分子ゲルである，こんにゃ く, 寒天, ゼリーや豆腐をイメージすると理解しやすい。 高分子ゲルは, 温度, 圧力, 水素イオン指数 ( $\mathrm{pH}$ 值), 光や電場等の外部刺激によって膨潤度が変わり, 体積が 
変化する。この特徵に注目し，機能材料・インテリジェ ント材料として, センサーやアクチュエータ等への応用 が研究・実用化されている。

また近年, ダブルネットワークゲル（以後, DN ゲル と記す）やナノコンポジットゲルと呼ばれる高強度ゲル やトポロジカルゲルと呼ばれる高勒性ゲルなどが開発さ れ，脆さに起因する取り扱い性の悪さの点が改善されて きたことから，工業用途での利用の広がりが期待され る。一方，高分子ゲルは固体でありながら主成分が液体 であるため, 著しく低い摩擦係数とユニークな摩擦挙動 を示すことが知られており，その独特の摩擦機構も明ら かにされつつある。よって, 高機能かつ高強度なゲルを 新規材料として産業界に送るためには, 新規材料として ゲルの摩擦を定量的に評価する必要がある。

本研究では, 世界最高強度を誇る DN ゲルと, 形状記 憶ゲル（以後, SMG と記す）を供試材として使用した。 DN ゲルの高強度化メカニズムは, 従来の弾性のみを考 慮した破壊モデルでは説明できないことから，各材料の 機械的特性ではなく, 硬いゲル, 軟らかいゲルからなる 特徵的な組織構造に由来するものと考えられている。

\section{2 ゲルについて}

新版高分子辞典 ${ }^{1)}$ によると, ゲルは「あらゆる溶媒 に不溶の 3 次元網目構造をもつ高分子およびその膨潤 体」と定義されている。ゲルは多数の高分子が化学・物 理的な架橋によって 3 次元的な網目を構成し, その網目 が水などの溶液を吸って膨潤したものである。このよう なものは我々の身近に数多く存在している。こんにゃく やゼリーなどの食品や, ポリビニアルアルコール (PVA) からなるソフトコンタクトレンズ，高吸収性を用いた紙 おむつなどがあげられる。さらに，生体も歯や骨，髪な どを除けばほとんどの体を構成するパーツはゲルである といえる。つまり, 私たちは最もゲルと身近な存在であ る $^{2)}$ 。

また，線状あるいは分岐高分子を良溶媒中に入れると しだいに溶媒を吸収して膨潤し，ついには個々の高分子 が完全に溶媒中に分散した溶解状態に達するのに対し, 3 次元網目構造を持つ架橋高分子では, 溶媒との相互作 用によってある程度までは膨潤するものの, 架橋構造を もつため有限の膨潤性を示す。前述した紙おむつに使わ れている高吸収性ゲルはゲル網目を構成する高分子と溶 媒が分子レベルで強固に相互作用しているので, 引っ 張ったり，潰したりしても吸収された溶媒がしみだして くることはない。

\section{$2 \cdot 1$ ゲルの特性 ${ }^{3,4)}$}

生体において, 硬組織である骨などを除くと, 大部分
を構成しているのがゲルである。構成物質は夕ンパク質 と多糖類であり，特に結合組織は主にコラーゲンとプロ テオグリカンから成る。眼球内の角膜・硝子体は主にコ ラーゲンと酸性ムコ多糖類により構成され, 水を大量に 含んだゲル状態である。

また，粘弾性以外にもゲル特有の性質は多い。その生 体材料のような柔軟性と水を保持する性質からソフトコ ンタクトレンズが開発され, 自重の数百倍もの水を吸収 できる高吸水性ゲルは生理用品やオムツなどに使用され ている。

ゲルの重要な特徴として，ゲル自身が非平衡状態にあ る開放系物質であることがあげられる。ゲルは構成する 高分子の種類によって導電性を示したり，構造規則性を 持ったり, $\mathrm{pH}$, 熱, 光, 電場などの外部刺激に応答す るなどの機能を有することが知られている。

さらに，金属材料や一般的な高分子材料は，体内での 親和性が低く少なからず拒否反応・炎症反応が起こるこ とが多いが, ゲルに関しては, 動物実験において生体親 和性が確認されているものもある ${ }^{5)}$ (Fig. 1)。

ゲルに含まれている溶媒の中には通常の液体とは異 なった状態で存在しているものもある。水の場合は網目 近傍に存在して網目路強く相互作用しているため, 低温 でも凍結しない結合水や, 不透水より離れてはいるが配 向により - 10〜 - $20^{\circ} \mathrm{C}$ まで凍らない束縛水, 相互作用が 弱く自由水として存在するものもある。植物の種子が極 低温でも生存していることの 1 つの要因として植物に含 まれる溶媒が網目との相互作用により結合水になり, 凍 結しないためだと考えられている。

\section{2 -2 ゲルの種類}

通常, ゲルは溶媒によって膨潤しており, その媒体が 水か有機溶媒かで大別できる。ほとんどのゲルは, 天然 高分子・合成高分子を問わず水を内包しているため, 一 般的にゲルといえば水媒体のハイドロゲルを指す。一方， シリコーンオイルなどの油性媒体の場合にはオルガノゲ ルと呼び，スポーツシューズや防震台などの衝撃吸収材 として用いられている。空気を媒体とするものはエアロ ゲル，またはキセロゲルと呼ばれる。

構成成分という点からみると, 生体高分子ゲルはタン パク質や多糖類でできており，こんにやくや豆腐などの 食品は生体から抽出した天然物で再構成された天然高分 子ゲルである。

一方, 合成高分子ゲルは日常的に用いられている高吸 水性オムツのポリアクリル酸ナトリウム (PNaAA), ソ フトコンタクトレンズなどのポリビニルアルコール (PVA) やポリヒドロキシエチルメタクリレート（PHE$\mathrm{MA})$, シリコーンハイドロゲルなどの, 水溶性の合成 


\section{High Water Content}

\section{More than $90 w t \%$ of water}

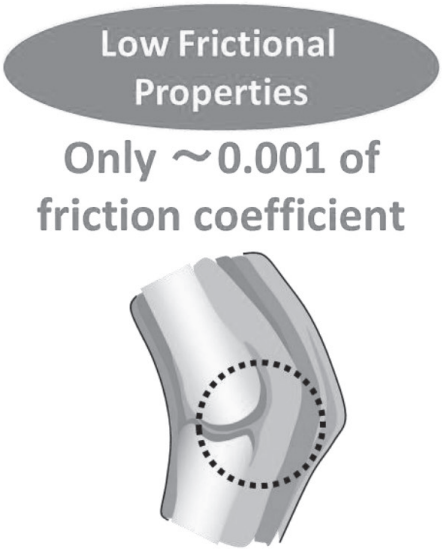

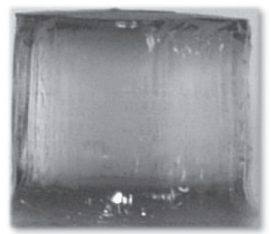

Material

Permeability

Red food coloring permeated gels.
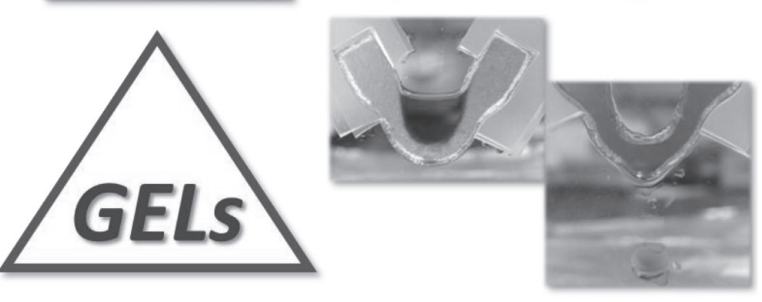

Fig. 1 The characteristics of gels: Gels have superior properties such as high water content, material permeability, especially low friction and biocompatibility, which are not found in hard and dry materials.

高分子由来のゲルを指す。

3 次元網目構造を形成する架橋方法において，化学反 応によって架橋・形成する化学ゲルと, 水素結合やイオ ン結合による凝集や高分子鎖の絡み合いにより形成され る物理ゲルとに大別できる。天然ものの多くは物理ゲル であり, 物理ゲルは温度, 溶媒, $\mathrm{pH}$, などの変化によっ てゾルーゲルの 2 形態での転移を可逆的に起こすが, 化 学ゲルは共有結合で架橋されたゲルであり, 鎖の分子運 動によってその結合が切れることなく, 再度溶解するこ とがない不可逆ゲルである。そのため, 化学ゲルの 3 次 元ネットワーク構造はゲルが形成された時点の構造がそ のまま固定される。

\section{$2 \cdot 33$ 次元網目架橋構造}

ゲルは，高分子の分子間相互架橋構造（ポリマーネッ トワーク）を持つことが必要である。ここで， 3 次元架 橋構造（ゲル）の機能について述べる。

ゲルのもつ網目サイズは $10^{-9} \mathrm{~m} \sim 10^{-6} \mathrm{~m}$ と極めて微 細なポリマーネットワークとして形成されている。その サイズは, $10^{9}$ 倍することにより実感できてくる。例えば, 直径 $1.2 \mathrm{~cm}$ のビー玉があるとする。このビー玉を $10^{9}$ 倍拡大するとちょうど地球サイズになる。また， $10^{9}$ 倍 縮小すると, ビーチボールの詰まった体育館は, 水分子 が詰まったイオン交換樹脂, 高吸水性樹脂（電解質ゲル） の網目サイズになり，ビーチボールの入った浴槽は，電 気泳動ゲル (中性ゲル) の網目サイズとなる。このとき の水分子の大きさは約 $0.3 \mathrm{~nm}$ ，対してビーチボールは 約 $30 \mathrm{~cm}$ とゲルの網目サイズの微細さがわかる(Fig. 2)。

ゲルの網目は, 微小空間を形成して特別な環境を創成

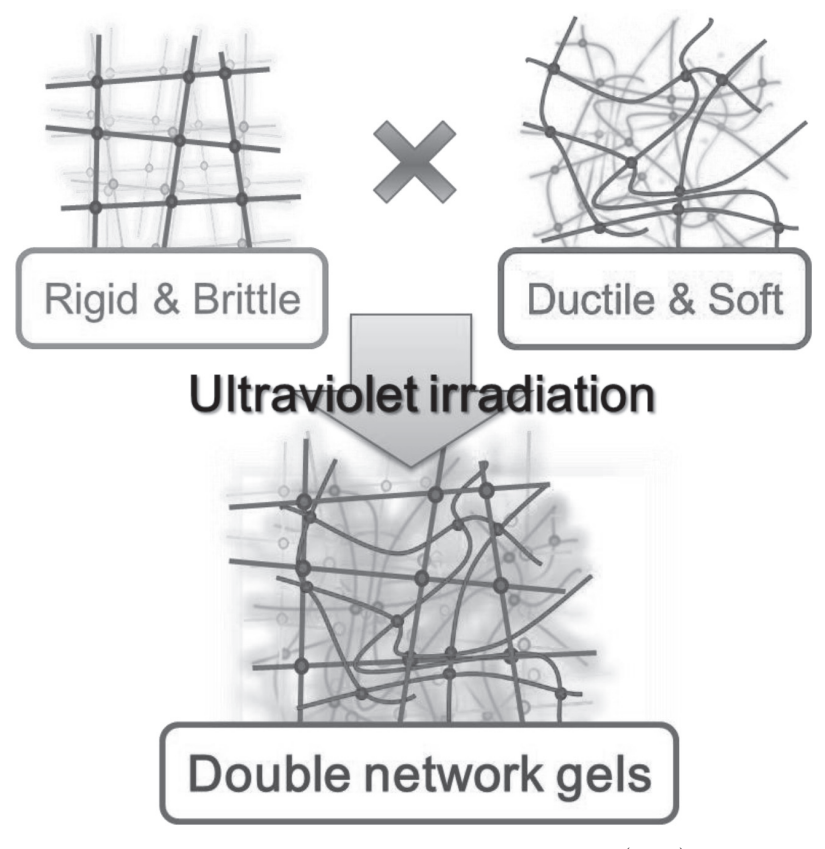

Fig. 2 The schematic of Double Network (DN) gel: DN gels has inter penetrate networks that is made with rigid-brittle $1^{\text {st }}$ gels and ductile-soft $2^{\text {nd }}$ gels.

する。そこでは, 篩機能や物質移動, ゲルを構成する高 分子と包括された溶質や溶液との原子・分子オーダーの 相互作用など，ゲルの原点でもある生体組織に似た機能 が発現される。

ゲルの 3 次元架橋構造の中は, 極めて接近した高分子 鎖と溶媒が溶質と共存する微小環境系が構築される。50 〜 70\%といった高分子密度の高い系は, 高重合度高分子 を溶解した濃厚溶液系ではとてもつくることはできな 
い。しかし，ゲルではこのような高密度系での高分子鎖 と溶質や溶媒の相関を知ることができ, 液体と固体の中 間の状態という特徵が生かされる。特に, 生体系では組 織自身の中で生体高分子の合成と架橋・ゲル化が同時に 行われるので, 精微な構造を形成し, 高い機能を発現す る。

\section{3 ゲル供試材について}

\section{$3 \cdot 1$ ゲルの合成}

化学架橋ゲルの調整に扔いて, ビニルモノマーとジビ ニルモノマー（架橋剤）のラジカル共重合反応は頻繁に 用いられる重合法である。モノマー, 架橋剂, 及び開始 剤を溶媒にとかし，熱または紫外線の刺激により開始剤 がラジカル化し，モノマーおよび架橋剤の成長反応が起 こり, 最終的には 3 次元網目を形成し高分子ハイドロゲ ルとなる。

\section{3・2 Double Network（DN）ゲルについて 6,7$)$}

Double Network（DN）ゲルは, 2003 年に襲らによ り創製され，合成高分子ゲルとしては異常ともいえる強 勒性を有するゲルである。高強度な生体軟組織である生 体軟骨は, 剛直なコラーゲン瀻維の 3 次元ネットワーク の内部にブラシのような構造を持つ柔軟なプロテオグリ カン集合体が存在する。つまり,「剛」と「柔」の要素 を併せ持つ複合材料であるといえる。この構造を模做し て作られたものが DN ゲルである。通常の DN ゲルは強 電解質で剛直な poly (2-acrylamido-2-methylpropanesulfonic acid）gel（PAMPS ゲル）を 1st netowork, 中性 で柔軟な polyacrylamide (PAAm) を2nd network と して相互侵入網目ゲル（IPN ゲル）を合成, Double Network ゲル（DN ゲル）となづけられた ${ }^{6,8,9)}$ (Fig. 3)。 特殊な組織構造を持つ DN ゲルは, 10〜 40 MPa 程度の 圧縮強度を有し, 表面の摩擦係数は約 0.01 と非常に低 い值を示している ${ }^{10,11)}$ 。この強度は生体軟骨が日常的 に受ける圧力 3 18 MPa を上回り，高分子ゲルがもつ 表面の低摩擦性や多量の水分保持機能力に上る物質透過 性なども保持していることから，人工関節への応用が期 待されている。また，DNゲルがもつ圧縮強度は DN ゲ ルを構成する個々のゲルと比べると 10１00 倍の值とな る ${ }^{12)}$ 。また，90\%程度圧縮しても破壊することなく， 荷重を除去すればゴムのように元の形に復元する。

DN ゲルの高強度化メカニズムは, 従来の弾性のみを 考慮した破壊モデルでは説明できないことから，各材料 の機械的特性ではなく, 硬いゲル, 軟らかいゲルからな る特徵的な組織構造に由来するものと考えている ${ }^{8)}$ 。

DN ゲルは使用するモノマーによって特性を変えるこ とが可能であり, 非常に伸びに強いものや, 非常に透明

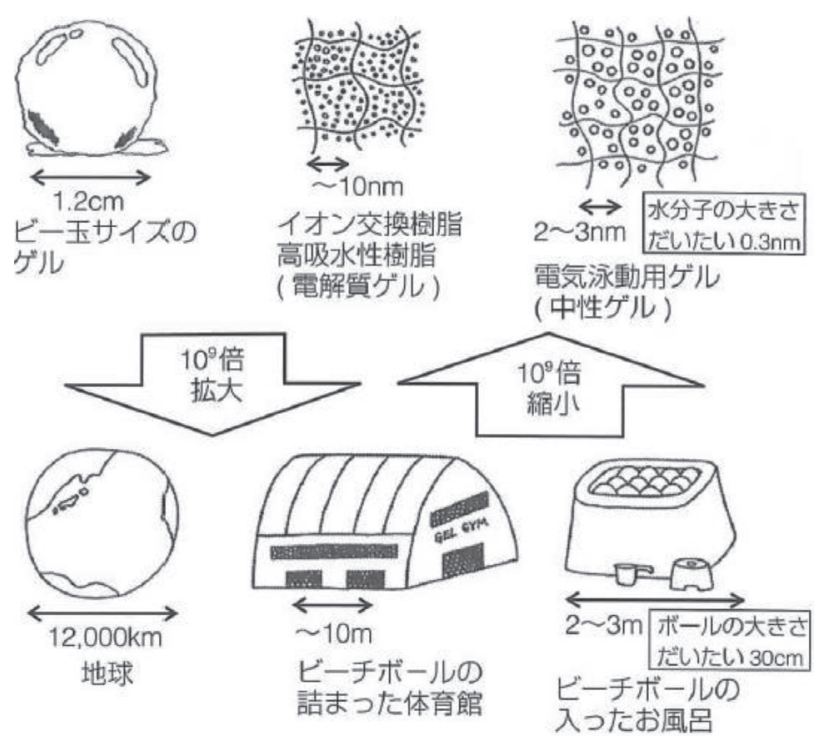

Fig. 3 Comparison between three-dimensional network of the gels ${ }^{19)}$.

な物, さらには表面摩擦係数が非常に小さいものなどを 合成することが可能である。

本実験では，1stゲルにはモノマーとして硫酸基をもつ PAMPS (2-acrylamido-2-methylpropane sulfonic Acid), 架橋剂として MBAA（ $N, N$ '-methylene bisacrylamide）, UV 開始剤として $\alpha$-keto ( $\alpha$-ketoglutaric acid)を用いた。 その濃度と比率は $1 \mathrm{M}, 4 \mathrm{~mol} \%, 0.1 \mathrm{~mol} \%$ とした。2nd ゲルにはモノマーとして中性の PDMAAm ( $N, N$-dimethyl acrylamide), 架橋剂として MBAA, UV 開始剤とし て $\alpha$-ketoを用いた。その濃度と比率は $2 \mathrm{M}, 0.02 \mathrm{~mol} \%$, $0.1 \mathrm{~mol} \%$ とした。

初めに1stゲルのモノマー, 及び架橋剤, 開始剤, 溶 媒を量りスターラーで量に応じて時間を調節し拡氾させ る。次に溶液中の酸素を除去するため, 窒素置換（バブ リング）を約 20 分行う。これは, 溶液中に含まれる酸 素が光開始剤の発生させたラジカルを吸収してしまうた めゲル化が阻害されるのを防ぐためである。バブリング 後, UV (紫外線) 照射によってゲル化を開始させる。 ゲル化の際容器の形に硬化するので, 本実験では厚さ $2 \mathrm{~mm}$ のコの字スペーサーを硝子板に挟んだもので約 8 時間 UV 照射を行った。UV 照射中に 2 nd 溶液を同様に 用意し，バブリング終了後できた 1 st ゲルを溶液の中に 浸し 2 日間膨潤させる。膨潤させた 1 st ゲルを適当な大 きさに切り, 硝子板に挟んで約 8 時間 UV 照射を行い, DN ゲルを製作した。この過程で製作した板状 DN ゲル から引張試験及び圧縮試験における試験片を型抜き機に よって製作する。

\section{$3 \cdot 3$ 形状記憶ゲル (SMG) について ${ }^{13-16)}$}

合金に形状記憶効果の生じることが見いだされたの 
は, 1951 年，米国での金一カドミウム合金を用いた研 究が最初のものとされており, 現在実用化されているチ タンーニッケル合金は, 1964 年頃, 米国の海軍兵器研 究所でチタンとニッケルの原子比が $1: 1$ ののだけに 形状記憶効果の発生することを偶然発見したのがその名 前の起源とされている ${ }^{17)}$ 。

多くの高分子材料はいわゆる粘弾性体であり，ゴム弾 性のように，外力による変形の関係が時間に依存するた め，その形状が前に受けた力学的影響を受ける。高分子 の形状記憶にはポリマーのガラス転移を利用したもの や，結晶成分を利用したもの，化学的および物理的刺激 を利用したものがあるが，本論文では結晶成分を利用し た形状記憶ゲルを用いることとする。

SMG は興味深い性質をもつ機能性材料である。所定 の温度以上で弾性率が急激に減少するため, 変形が容易 に可能となる。また変形状態のまま泠却させていくと外 力を取り除いても変形状態を維持できるようになり,さ らに再び加熱するとゲルはもとの状態に戻る。アクリル 酸ステアリル（SA）を用いることにより，室温にて SA のアルキル側鎖の結晶化による秩序構造を持つことで硬 いが, 温度を高くしていくと結晶の融解が起こり容易に 変形可能となる (Fig. 4)。

当研究室では透明形状記憶ゲル（T-SMG）の開発に 成功した。通常ゲルを合成するにあたり溶媒を必要とす るが，この溶媒の役割をモノマーで代用することによる 無水合成法が考案され, 疎水性である SA と親水性であ る PDMAAm の共重合化が可能となった。合成された T-SMG はSMG と同様に結晶一アモルファス転移を示
し形状記憶特性を持ちながらも，常温で非常に透明であ

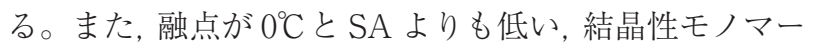
であるラウリルアクリレート（LA）も使用した。

本実験では，形状記憶ゲルにはモノマーとして SA と PDMAAm を用いた ${ }^{18)}$ 。架橋剤には MBAAm, 反応開 始剤にはベンゾフェノンを用いた。これらの薬品は全て 未精製で使用した。また, 融点が $0^{\circ} \mathrm{C}$ とAよりも低い, 結晶性モノマーである LA も使用した。PDMAAmが $3 \mathrm{~mol} / \mathrm{L}$ に対し MBAA が $1 \mathrm{~mol} / \mathrm{L}$ ，またこれらのモノ マーに対して MBAA が $0.2 \mathrm{~mol} \%$, ベンゾフェノンが $0.4 \mathrm{~mol} \%$ の配分で合成した。

\section{4 ゲルの摩擦測定}

\section{$4 \cdot 1$ 研究の背景と目的}

先に述べたように，高機能を有するゲルが次々に開発 され，そのゲルを用いた研究も盛んに行われている。高 分子ゲルは固体でありながら主成分が液体であるため, 著しく低い摩擦係数とユニークな摩擦挙動を示すことが 知られており, その独特の摩擦機構 ${ }^{12)}$ も明らかにされ つつある。機械部品間で発生する摩擦損失の低減や, 医 療用材料への応用を目的に, 高分子ゲルの優れた低摩擦 特性を利用することを考えた場合, ゲルの摩擦を定量的 に評価する必要がある。そのため, DN ゲルの低摩擦性 の解明を目的に, 測定方法の確立, 測定值の評価など最 適な摩擦試験方法の提案を目指し, 本報では, DN ゲル と, $\mathrm{SMG}^{18)}$ について, さまざまな条件でのガラス球 (ソー ダガラス）に対する摩擦特性を報告する。

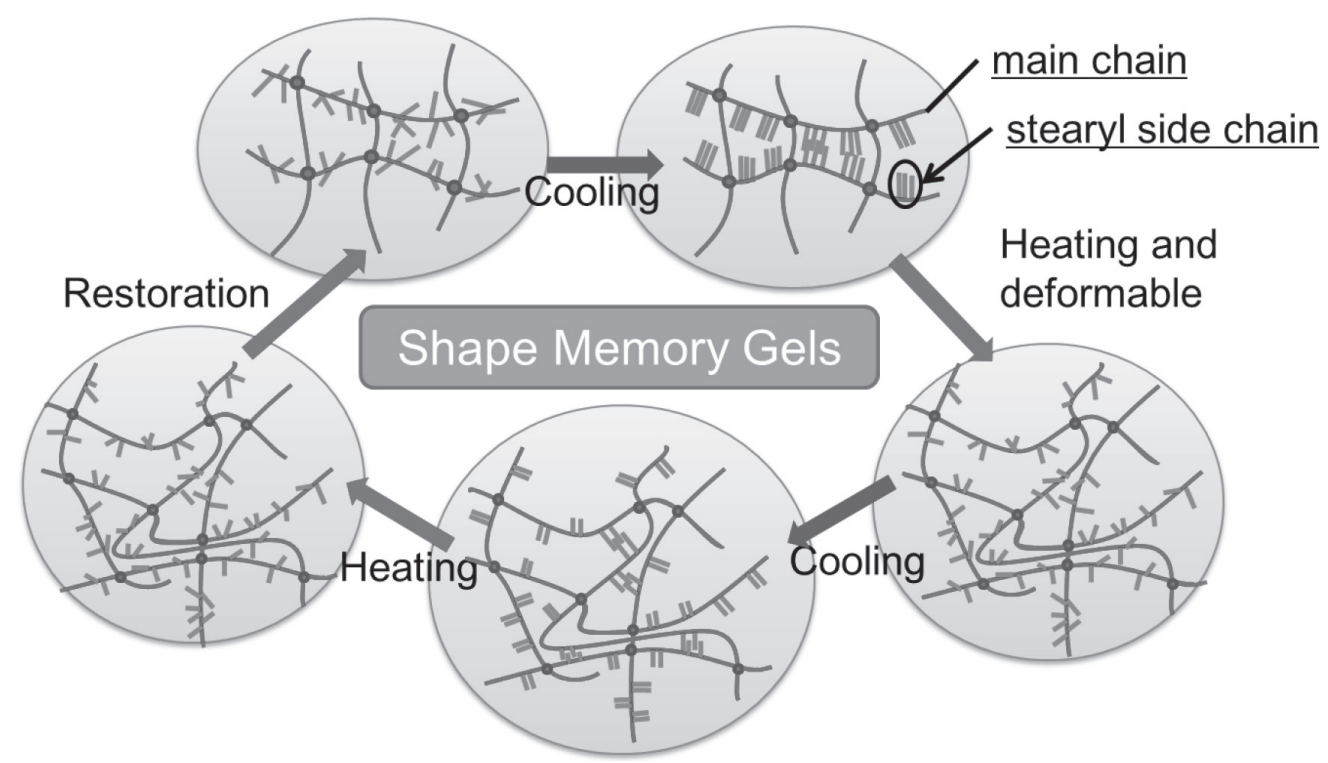

Fig. 4 The schematic of Shape Memory Gel (SMG): The main chain of SMG is made by flexible and crystalline monomer. The property of crystalline monomer is depending on temperature, that is, it can be flexible by heating and it can keep the shape by cooling. 


\section{$4 \cdot 2$ 摩擦測定装置}

摩擦試験機は, 速度変動摩擦測定機 $\mu \mathrm{V} 1000$ （株式会 社トリニティーラボ製）を用いた。一連動作で $0.1 〜$ $100 \mathrm{~mm} / \mathrm{s}$ まで 1000：1の可変速度範囲で, 最大 7 段階 の速度で摩擦データを一度に収集することが可能であ る.この機能を用いず速度一定での測定も可能である。 摩擦試験方法の概要を Fig. 5 に示す。図中のテーブル上 にある保持具内の板状の試験片がゲルであり，ボール部 が接触相手材である。今回, 接触相手材としてソーダガ ラスを用いた。接触相手材側に荷重を負荷し, 試験片を 固定しているテーブルを動かして摩擦試験を行った。摩 擦係数は，ロードセルにより検出した摩擦力を試験荷重 で除することで算出した。試験条件を Table 1 に示す。

\section{$4 \cdot 3$ ゲル保持具}

ゲルは金属とは違い, 粘弾性体であり低摩擦な特性を
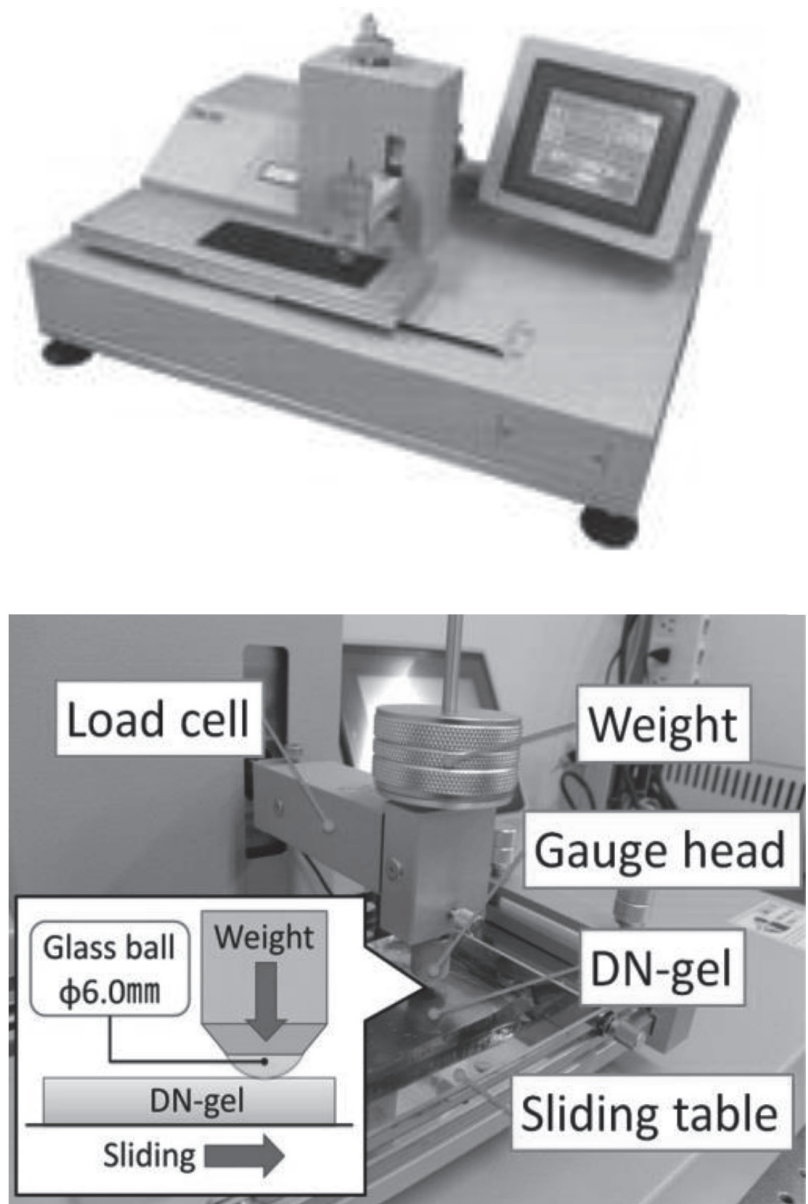

Fig. 5 Detailed drawing of the measurement part of the friction measuring machine.
もっているため固定が容易ではない。ゲルの固定法につ いては低摩擦材料ゆえに, 物理固定か化学接着かで現在 議論されているところである。我々は化学接着の研究も 行っているが，現在の固定方法は物理固定を採用してい る。ゲル側面と上面からの押付固定し，押付板，保持具 本体には高摩擦処理を施している。また, 温度変化に伴 う摩擦係数を測定するため水槽型の加温ゲル保持具を製 作した（Fig. 6, 7)。

\section{5 実験結果}

\section{$5 \cdot 1$ 力学的性質の比較}

ゲルの力学的強度の測定にはシングルコラム型引張圧 縮試験機（A\&D 社，STA-1150）（Fig. 8）を用いた。シ ングルコラム型引張圧縮試験機は本体と計測制御部, 及 びデー夕処理用 PC で構成されている。本体は固定クロ スヘッド (引張試験時), 移動クロスヘッド, 及びロー ドセルで構成されている。データは計測制御部から付属 の PCにリアルタイムで転送，記録される。圧縮試験の 際は圧縮試験用クロスヘッドを用いて圧縮測定を行っ た。

\section{$5 \cdot 1 \cdot 1$ サンプルの形状と設置法}

圧縮試験用サンプルはシート状サンプルから，コルク ボウラーを用いて $\phi 5.5 \mathrm{~mm}$ 切り出したものを用いた。 引張試験器の治具を備え付けの圧縮試験機用のものに取 り換え行った。

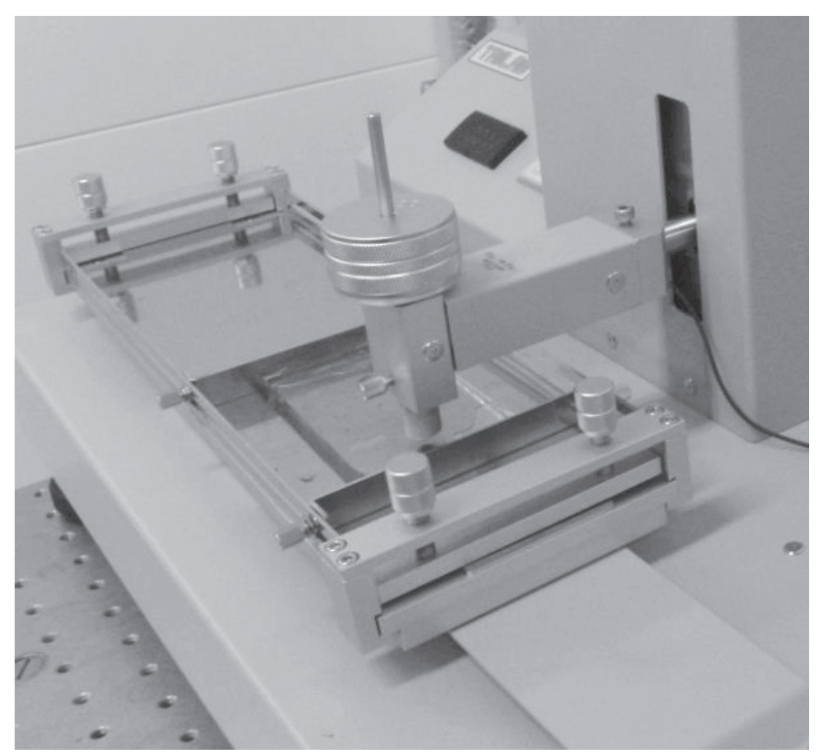

Fig. 6 Fixture of gels.

Table 1 Conditions of Seven-step Continuous Friction Measurement

\begin{tabular}{|c|c|c|c|c|c|c|c|}
\hline \multicolumn{1}{|c|}{ Step } & 1 & 2 & 3 & 4 & 5 & 6 & 7 \\
\hline Speed $(\mathrm{mm} / \mathrm{s})$ & 0.1 & 0.5 & 1.0 & 5.0 & 10.0 & 50.0 & 100.0 \\
\hline Distance $(\mathrm{mm})$ & 1.0 & 2.0 & 2.0 & 5.0 & 5.0 & 10.0 & 25.0 \\
\hline
\end{tabular}




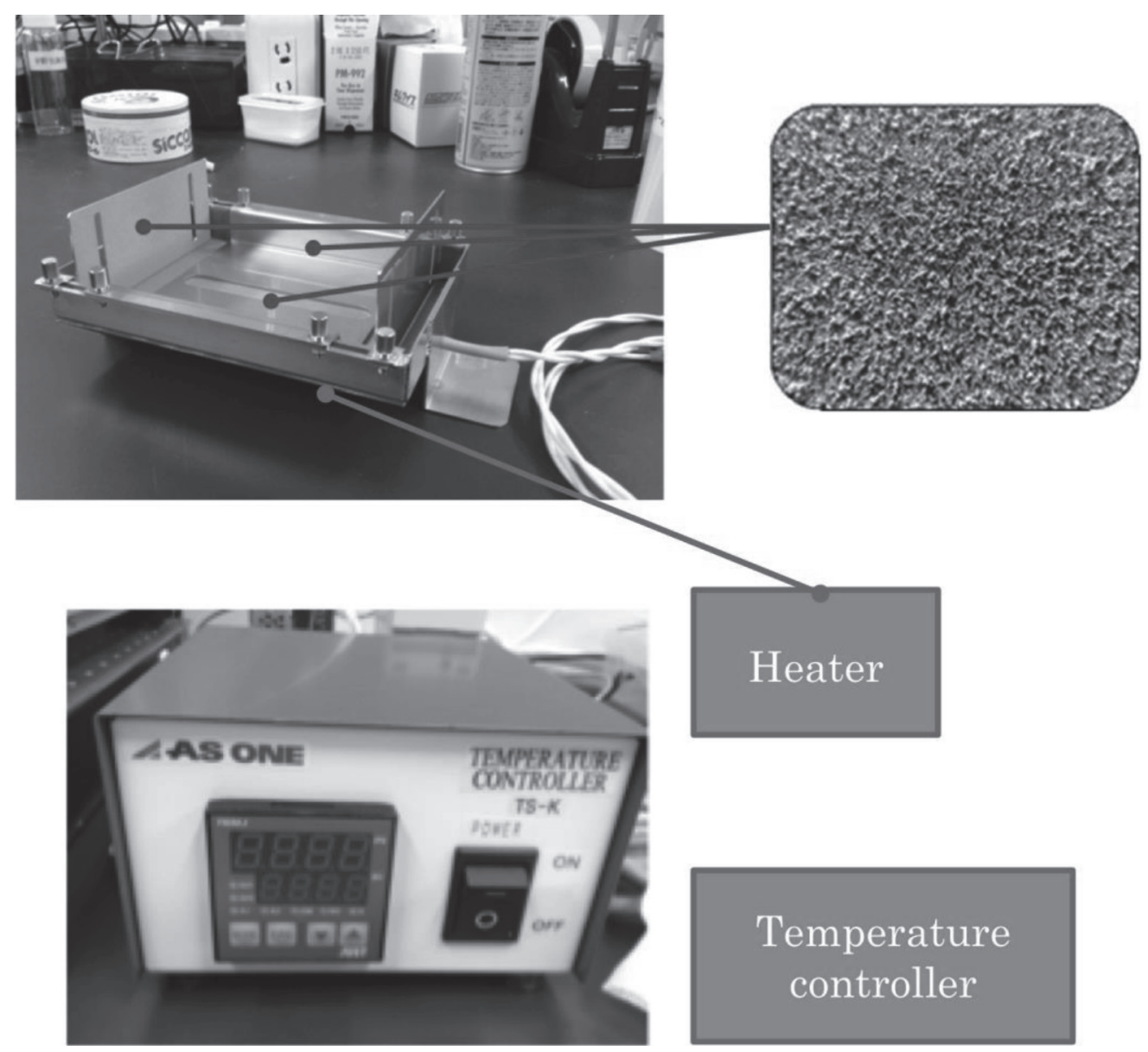

Fig. 7 High friction surface fabricational fixture of gels and Temperature controller.

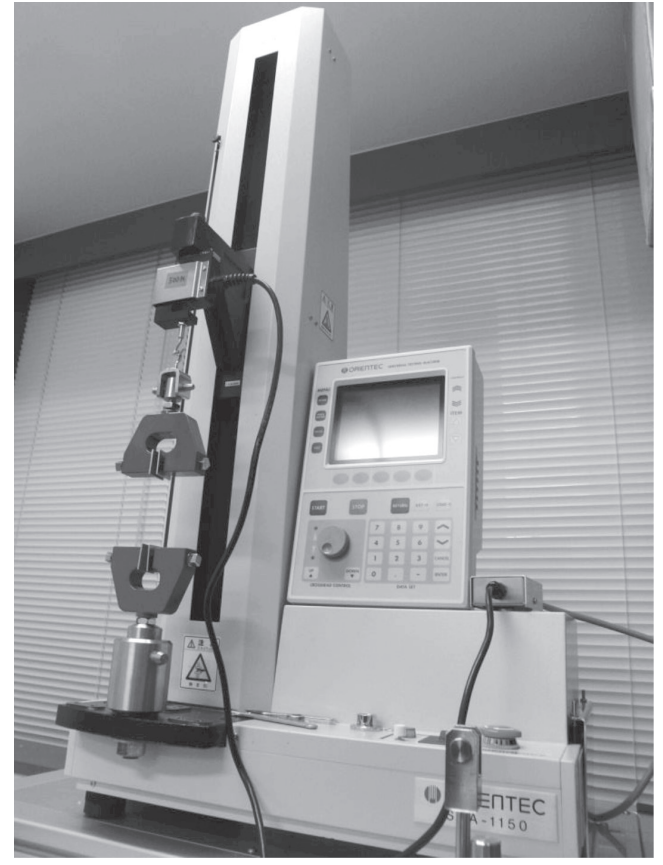

Fig. 8 Single column model tension and compression fatigue tester STA-1150.

\section{$5 \cdot 1 \cdot 2$ 測定方法}

圧縮試験機では試験速度 $50 \mathrm{~mm} / \mathrm{min}$ で行った。得ら れた応力ーひずみ曲線から破断応力 $\sigma$, 破断ひずみ $\varepsilon$ を 決定した。DN ゲルと SMGの圧縮試験での S-S 曲線を Fig. 9 に示す。図に示すようにDN ゲルの, 圧縮破断応 力は, $10 \mathrm{MPa}$ 以上だった。一方, SMGは, 乾燥状態と 濡れ状態によって違いが現れる。また，温度変化によっ ても支配される特性がある。さらに，60における S-S 曲線は J 型の曲線を示す。これは, SMGがゴムのよう にふるまうことを意味している。

\section{$5 \cdot 2$ 速度変動摩擦測定}

DN ゲルと SMGの動摩擦係数を測定した值を Fig. 10 に示す。DNゲルと SMGの動摩擦係数は, ステップ 2 からステップ 7 の範囲で，低い值に落ち着くことが見て とれる。摩擦速度が $1.0 \mathrm{~mm} / \mathrm{s}$ 以上では低い摩擦係数を 示し, SMGに関しては荷重が大きいほど低摩擦な挙動 を示している。

\section{$5 \cdot 3$ 温度可変摩擦測定}

現在の研究において, LA-SMG の摩擦の係数の温度 依存は, 我々が知る限り初めて測定された。温調可能バ スタブ型ゲル固定具を作製し，温度を変化させながら 


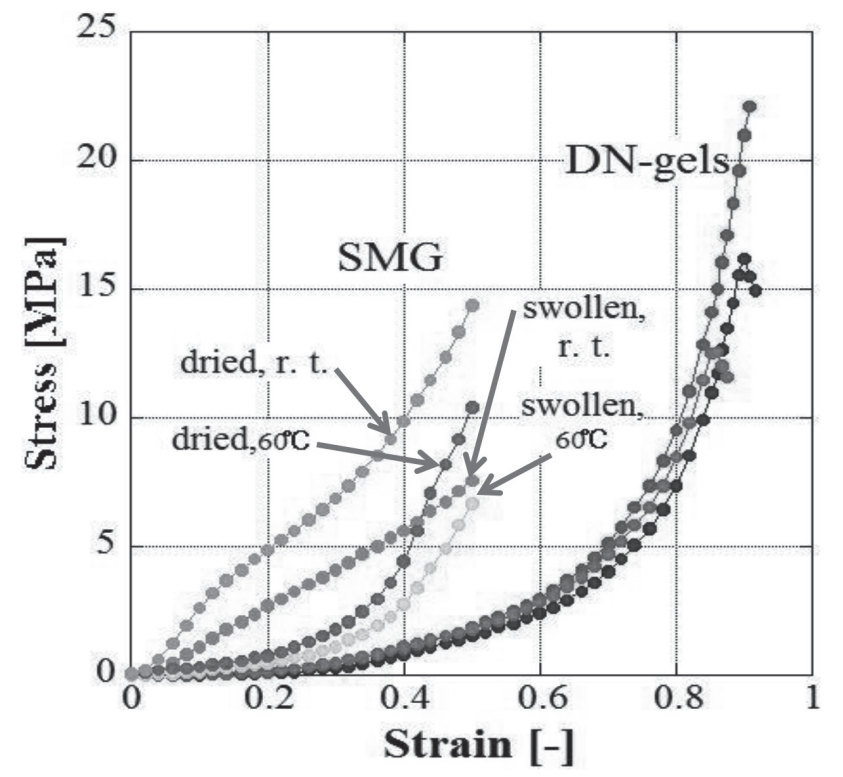

Fig. 9 Compression test results for the DN-gels and $\mathrm{SMG}^{20)}$.

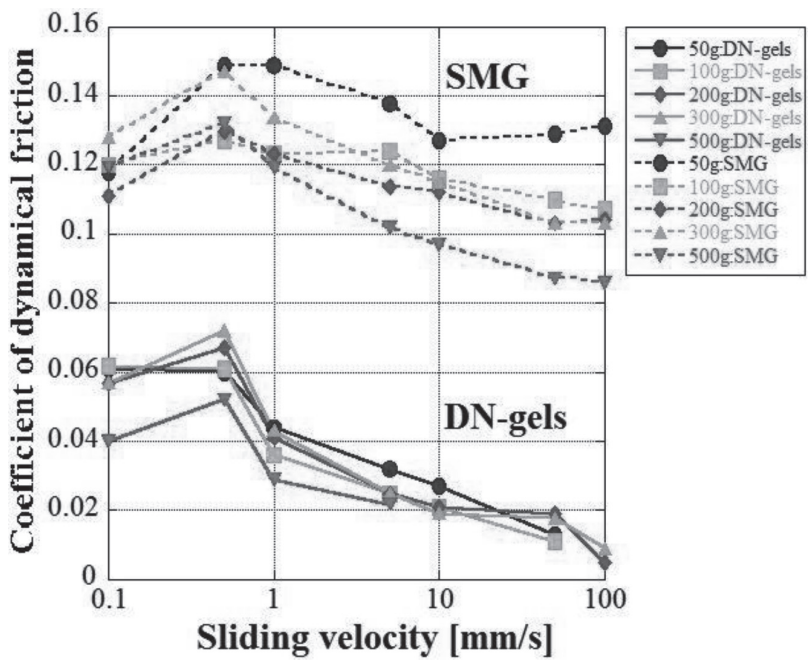

Fig. 10 Relations of a dynamical friction coefficient and the sliding velocity of the DN-gels and the SMG at room temperature ${ }^{20)}$.

LA-SMG の表面摩擦測定を行った。垂直荷重 $100 \mathrm{gf}$ 一 定下でのすべり速度に関しての結果，すべり速度 $1 \mathrm{~mm} / \mathrm{s}$ 一定下での垂直荷重に関しての結果をそれぞれ Fig. 11，Fig. 12 に示す。尚，測定值は 5 回測定の平均を 用いた。

Fig. 11 で示すように，速度が高速域になるにつれ温 度変化に関倸なく，動摩擦倸数は減少する傾向がある。 温度が $30^{\circ} \mathrm{C}$ から $35^{\circ} \mathrm{C}$ まで上がると, 全体の動摩擦係数 が増加している。また，温度が $40^{\circ} \mathrm{C}$ になると，動摩擦 係数のカーブの様子が単調減少のカーブから非単調カー ブに変化している。それは，おそらく温められたことに よる LA-SMG の表面上の特性の変化に関連があると考 えられる。さらには, $40^{\circ} \mathrm{C}$ ありの転移温度を上回ると,

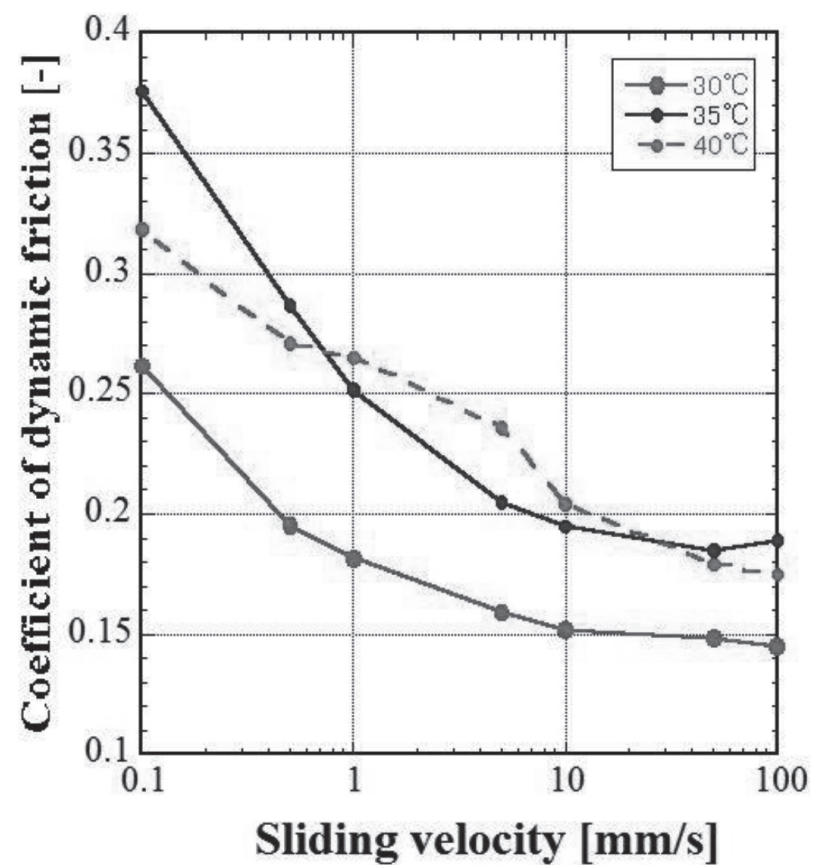

Fig. 11 Relations of the fitted dynamical friction coefficient and the sliding velocity of the LA-SMG with the temperature change ${ }^{21)}$.

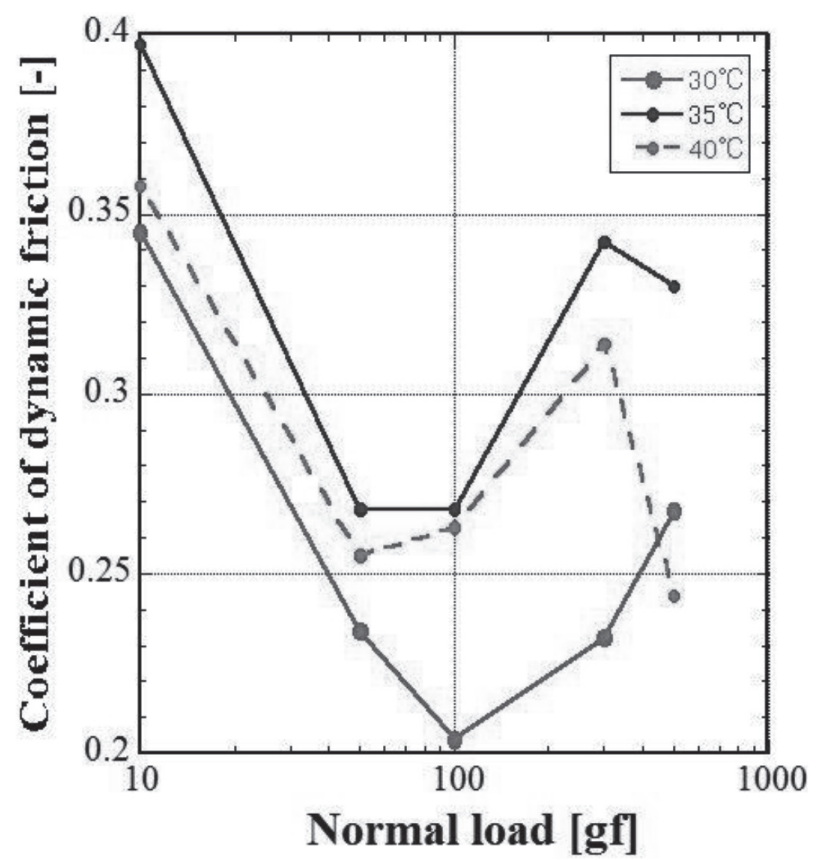

Fig. 12 Relations of the fitted dynamical friction coefficient and the normal load of the LA-SMG with the temperature change at $1 \mathrm{~mm} / \mathrm{s}^{21)}$.

表面はより柔らかくてより粘着性が増す。我々は, 粘着 性が扔そらく摩擦の増加を誘発すると考える。Fig. 12 は, 係数の垂直荷重依存性を表している。そ机は, 動摩 擦係数が垂直荷重 $100 \mathrm{gf}$ 周辺において, 極小点を持つ ことを意味する。颃そらく温度が増加したことによりゲ ル表面が柔らかくなることが影響している。 


\section{6 結論}

摩擦速度の高速領域での摩擦の低減がみられることよ り, 低速領域では固体潤滑状態であり, 高速領域では流 体潤滑状態にあると考える。一般的な材料はこのような 荷重・速度条件下では流体潤滑になり得ない。したがっ て, DN ゲルは従来の常識からは考えられない領域から 流体潤滑による低摩擦摺動が可能で，かつゲル材料とし ても従来にない高強度を持ち合わせた，非常にユニーク な材料であると考える。SMGに関しては似たような摩 擦挙動を示すが，緩和近似後の動摩擦係数をみるかぎり 高速領域にて流体潤滑状態であるとは言い難い。また温 度変化による摩擦係数の増加が確認できた。また, 機器 やプログラムでは低摩擦なゲルを固定できるゲル保持具 や温度可変ゲル保持具を作製した。粘弾性体の摩擦測定 ができるようゲル専用の測定プログラムへと変更した。 さらに，実際にゲルの摩擦界面を観察できるよう，偏光 顕微摩擦測定装置の共同開発を行った。

しかし，ゲルのような粘弾性特性をもった材料には接 触面積によるエネルギー損失などの摩擦に関する影響因 子がたくさんある。ゲルを新規材料として定量的な評価 を行う必要があり, さらに丁寧な測定・評価が必要であ る。

\section{文 献}

1）高分子学会編，「新版高分子辞典」, 朝倉書店, (1998).

2) Osada, Y.; Kajiwara, K. "Gels Handbook”, Academic Press, Vol. 1-4 (2003).

3）長田義仁, 萩野一善, 伏見隆夫, 山内愛造,「ゲル」, 産業図書, (1991).

4）高分子学会編集, 吉田亮, 「高分子ゲル」, 共立出版, (2004).

5) Yasuda, K.; Kitamura, N.; Gong, J. P.; Arakaki, K.; Kwon, H. J.; Onodera, S.; Chen, Y. M.; Kurokawa, T.; Kanaya, F.; Ohmiya, Y.; Osada, Y. Macromol. Biosci. 9, 307 (2009)

6) Gong, J. P.; Katsuyama, Y.; Kurokawa, T.; Osada, Y. "Double Network Hydrogels with Extremely High Mechanical Strength", Advanced Materials, Vol. 15
No. 14, pp. 1155-1158 (2003).

7) Huang, M.; Furukawa, H.; Tanaka, Y.; Nakajima, T.; Osada, Y.; Gong, J. P. "Importance of Entanglement between First and Second Components in HighStrength Double Network Gels" Macromolecules, Vol.40, No.18, pp. 6658-6664 (2007).

8) Gong, J. P. "Double Network Hydrogel with High Modulus and Toughness: A Novel Material for LoadBearing Soft Tissues", Kobunshi High Polymer, 58 (5), 321 (2009).

9) Furukawa, H.; Gong, J. P. "Tough Hydrogel-Learn from Nature", Advances in Science and Technology, 61, 40-45 (2008).

10) Gong, J. P. Soft matter. 2, 544-552 (2006).

11) Kamada, K.; Furukawa, H.; Kurokawa, T,; Tada, T.; Tominaga, T.; Nakano, Y.; Gong, J. P. Journal of Physics, Condensed Matter, 23, 284107 (7pp) (2011).

12) Gong, J. P.; Kagata, G.; Iwasaki, Y.; Osada, Y. “Surface friction of polymer gels 1 . Effect of interfacial interaction”, Wear, 251, 1183-1187 (2001).

13）日出間るり, 吉沢泰介, Khairi Bin NASARUDDIN, 古川英光, “形状記憶ゲルの纎維強化による自己修復材 の創製”, 日本機械学会論文集 (A 編), Vol.77, No. 777, pp. 764-768 (2011).

14) Yokoo, T.; Hidema, R.; Furukawa, H. Journal of Solid Mechanics and Materials Engineering, 5 (12), 10152021 (2011).

15) Amano, Y.; Hidema, R.; Gong, J.; Furukawa, H. Chemistry Letters, 41 (10), 1029-1031 (2012).

16) Harada, S.; Hidema, R.; Gong, J.; Furukawa, H. Chemistry Letters, 41 (10), 1047-1049 (2012).

17）清水謙一ほか, 「記憶と材料」，共立出版，（1986）.

18) Osada, Y.; Matsuda, A. "Shape memory in hydrogels", Nature, Vol.376, No.6537, pp. 219 (1995).

19）日出間るり, 古川英光, 工業材料, 4, 69-73 (2011).

20) Wada, M.; Hidema, R.; Chiba, T.; Yamada, K.; Yamada, N.; Gong, J.; Furukawa, H. Surface and Bulk Mechanical Properties of Soft and Wet Materials. Journal of Solid Mechanics and Materials Engineering, 7 (2), 228-234 (2013).

21) Wada, M.; Gong, J.; Makino, M.; Kabir, M. H.; Furukawa, H. Surface friction of double network gels and shape memory gels. Proceedings of the 12th Asia Pacific Physics Conference JPS Conf. Proc. 012042(2014). 